\title{
Untangling the Biological Contributions to Soil Stability in Semiarid Shrublands
}

\author{
V. Bala Chaudhary \\ Loyola University Chicago, vchaudhary@luc.edu \\ Matthew A. Bowker \\ Thomas E. O'Dell \\ James B. Grace \\ Andrea E. Redman
}

See next page for additional authors

Follow this and additional works at: https://ecommons.luc.edu/ies_facpubs

Part of the Ecology and Evolutionary Biology Commons

\section{Recommended Citation}

V. Bala Chaudhary, Matthew A. Bowker, Thomas E. O'Dell, James B. Grace, Andrea E. Redman, Matthias C. Rillig, and Nancy C. Johnson 2009. Untangling the biological contributions to soil stability in semiarid shrublands. Ecological Applications 19:110-122. http://dx.doi.org/10.1890/07-2076.1

This Article is brought to you for free and open access by the Faculty Publications and Other Works by Department at Loyola eCommons. It has been accepted for inclusion in School of Environmental Sustainability: Faculty Publications and Other Works by an authorized administrator of Loyola eCommons. For more information, please contactecommons@luc.edu. c) $($ ) $(9)$

This work is licensed under a Creative Commons Attribution-Noncommercial-No Derivative Works 3.0 License. (c) Ecological Society of America, 2009. 


\section{Authors}

V. Bala Chaudhary, Matthew A. Bowker, Thomas E. O'Dell, James B. Grace, Andrea E. Redman, Mathias C. Rillig, and Nancy C. Johnson 


\title{
Untangling the biological contributions to soil stability in semiarid shrublands
}

\author{
V. Bala Chaudhary,,${ }^{1,7}$ Matthew A. Bowker,,${ }^{1,2}$ Thomas E. O'Dell,${ }^{3}$ James B. Grace, ${ }^{4}$ Andrea E. Redman,, 5 \\ Matthias C. Rillig, ${ }^{6}$ and Nancy C. Johnson ${ }^{1}$ \\ ${ }^{1}$ Department of Biological Sciences, Northern Arizona University, Flagstaff, Arizona 86011-5640 USA \\ ${ }^{2}$ Área de Biodiversidad y Conservación, Universidad Rey Juan Carlos, c/ Tulipán s/n, E-28933 Móstoles (Madrid), Spain \\ ${ }^{3}$ The Remediators Incorporated, 905 West 9th Street, Suite 222, Port Angeles, Washington 98363 USA \\ ${ }^{4}$ USGS National Wetlands Research Center, Lafayette, Louisiana 70506 USA \\ ${ }^{5}$ Western Ag Innovations, 3631 Kays Road, Wapato, Washington 98951 USA \\ ${ }^{6}$ Plant Ecology, Freie Universitët Berlin, Altensteinstraße 6, D-14195 Berlin, Germany
}

\begin{abstract}
Communities of plants, biological soil crusts (BSCs), and arbuscular mycorrhizal (AM) fungi are known to influence soil stability individually, but their relative contributions, interactions, and combined effects are not well understood, particularly in arid and semiarid ecosystems. In a landscape-scale field study we quantified plant, BSC, and AM fungal communities at 216 locations along a gradient of soil stability levels in southern Utah, USA. We used multivariate modeling to examine the relative influences of plants, BSCs, and AM fungi on surface and subsurface stability in a semiarid shrubland landscape. Models were found to be congruent with the data and explained 35\% of the variation in surface stability and $54 \%$ of the variation in subsurface stability. The results support several tentative conclusions. While BSCs, plants, and AM fungi all contribute to surface stability, only plants and AM fungi contribute to subsurface stability. In both surface and subsurface models, the strongest contributions to soil stability are made by biological components of the system. Biological soil crust cover was found to have the strongest direct effect on surface soil stability $(0.60$; controlling for other factors). Surprisingly, AM fungi appeared to influence surface soil stability (0.37), even though they are not generally considered to exist in the top few millimeters of the soil. In the subsurface model, plant cover appeared to have the strongest direct influence on soil stability (0.42); in both models, results indicate that plant cover influences soil stability both directly (controlling for other factors) and indirectly through influences on other organisms. Soil organic matter was not found to have a direct contribution to surface or subsurface stability in this system. The relative influence of AM fungi on soil stability in these semiarid shrublands was similar to that reported for a mesic tallgrass prairie. Estimates of effects that BSCs, plants, and AM fungi have on soil stability in these models are used to suggest the relative amounts of resources that erosion control practitioners should devote to promoting these communities. This study highlights the need for system approaches in combating erosion, soil degradation, and arid-land desertification.
\end{abstract}

Key words: arbuscular mycorrhizal fungi; arid ecosystems; biological soil crusts; erosion control; soil stability; structural equation modeling (SEM).

\section{INTRODUCTION}

Organisms that inhabit the soils of all ecosystems, such as plants, invertebrates, fungi, and bacteria, mediate the formation and maintenance of soil structure and stability. Christensen et al. (1996) highlight the maintenance of soils as an important ecosystem service and emphasize the need to understand the processes behind such services in order to manage sustainable ecosystems. We define soil structure as the spatial arrangement of soil particles (i.e., aggregation) and soil stability as the ability of soils to resist erosive forces. Soil

Manuscript received 18 December 2007; accepted 4 April 2008; final version received 6 June 2008. Corresponding Editor: J. Belnap.

${ }^{7}$ E-mail: vbc2@nau.edu structure and stability are ecosystem properties, while their formation and maintenance can be considered to be ecosystem services. A substantial body of literature shows that, individually, soil organisms strongly influence soil structure and stability (Belnap and Gardner 1993, Angers and Caron 1998, Miller and Jastrow 2000, Rillig 2004). However, the myriad of interactions among soil biota, and the corresponding net effects of these interactions on soil stability, represent a level of complexity that soil ecologists are only beginning to understand. In arid and semiarid ecosystems, where soils are particularly fragile and susceptible to erosion (Dregne 1983), the interactions of soil organisms and their effects on soil stability are poorly understood. Yet, soil erosion and loss are implicated as both symptoms and causes of desertification (Schlesinger et al. 1990, 
UNCCD 1994, Reynolds et al. 2007) and the eventual "collapse" of functioning ecosystems and human societies (Diamond 2005). The scientific and ecological challenge lies in understanding how soil organisms interact in natural ecosystems to influence soil stability. Understanding the major mechanisms that generate and maintain soil stability in arid lands will help ecosystem managers improve efforts to control erosion and combat desertification.

In this study, we examined the combined effects of plants, biological soil crusts (BSCs), and arbuscular mycorrhizal (AM) fungi as major drivers of soil stability in dryland ecosystems. These different communities of organisms can strongly influence soil stability, but likely function in different ways and on different scales. Plant roots and root exudates bind soil microaggregates $(<250$ $\mu \mathrm{m})$ together, forming macroaggregates $(>250 \mu \mathrm{m})$ and stabilizing rhizosphere soil. In addition, aboveground and belowground plant litter contributes to soil organic matter pools, which promote soil structure and stability (Tisdall and Oades 1982). In many semiarid shrublands, dominant shrub species occur in "fertility islands" (Fig. 1) that are separated by a matrix of comparatively unfertile soil (Schlesinger et al. 1996, Schlesinger and Pilmanis 1998). Shrub islands and their associated litter resist physical erosive forces from raindrops and surface runoff, while unvegetated interspaces have been found to be particularly susceptible to wind and water erosion (Abrahams et al. 1995.)

Biological soil crusts, communities of primarily mosses, lichens, and cyanobacteria, inhabit soil surfaces in the unvegetated matrix of undisturbed landscapes and promote soil stability in arid and semiarid ecosystems (reviewed in Belnap et al. 2001). Cyanobacterial filaments help bind soil particles together to form microaggregates (Belnap and Gardner 1993). BSC communities have the potential to reduce soil erosion by increasing water infiltration rates, decreasing raindrop impact, and decreasing surface runoff (reviewed in Warren 2001). These communities also reduce wind erosion because soil aggregates linked by cyanobacterial polysaccharides require greater wind velocity to move compared to single grains (Marticorena et al. 1997). In addition, BSCs contribute to surface organic matter pools and alter soil fertility by $\mathrm{N}$ fixation. These soil surface communities are a dominant component of many arid ecosystems and, in undisturbed areas, can make up $>70 \%$ of living cover across the landscape (Belnap et al. 2003).

Another major component of arid ecosystems, AM fungi, have a strong potential role in soil stability. The majority of plants in arid ecosystems associate with AM fungi and support diverse communities of these ubiquitous root symbionts (Stutz et al. 2000, Chaudhary 2006). These fungi deliver a variety of benefits to plants (e.g., increased nutrient uptake, improved water relations, protection from pathogens) in exchange for photosynthates (Newsham et al. 1995). Arbuscular mycorrhizal



FIG. 1. Location of the Grand Staircase-Escalante National Monument (GSENM) in southern Utah, USA, and the four sampling regions, each containing a low (L), medium (M), and high $(\mathrm{H})$ stability site. The inset photograph typifies a single site, illustrating "shrub islands" and microsite heterogeneity across the landscape.

fungi have been found to physically stabilize soil through the enmeshment of soil particles by filamentous hyphal networks and the production of glomalin, a putative heat-shock protein homolog (Gadkar and Rillig 2006), quantified in soils as operationally defined glomalin-related soil protein (GRSP; Wright and Upadhyaya 1996, Miller and Jastrow 2000, Rillig 2004). Glomalin is a component of the hyphal walls of AM fungi, which likely remains recalcitrant in soils following hyphal decomposition (Driver et al. 2005, Gadkar and Rillig 2006). Both hyphal density and GRSP concentration in soils have been found to be strongly correlated with aggregate stability in mesic soils (Wright and Upadhyaya 1998). In a tallgrass prairie, AM fungal hyphal density was found to have a stronger direct effect on percent macroaggregation than fine roots $(0.2-1.0 \mathrm{~mm}$ diameter), very fine roots $(<0.2 \mathrm{~mm}$ diameter), organic carbon, microbial biomass, or inorganic carbonates (Jastrow et al. 1998). Arbuscular mycorrhizal fungi may play an important role in generating and maintaining soil stability in arid ecosystems, though our knowledge of their contribution compared to other biotic and abiotic components of the system remains speculative.

Understanding the contributions to soil stability of biotic components of arid ecosystems is important for a number of reasons. First, drylands make up roughly 
$41 \%$ of terrestrial ecosystems (Reynolds et al. 2007), yet the majority of erosion models have been developed in mesic agroecosystems, and their application in natural dryland ecosystems has proved inappropriate (Pierson 2000). Second, severe soil erosion results in desertification, which the United Nations recognizes as a major economic, social and environmental problem facing societies even designating 17 June as the World Day to Combat Desertification (UNCCD 1994, Cardy 2000). Desertification results in a decline in the quality and quantity of natural assets such as soil, water, and biodiversity (Narjisse 2000). Drylands are home to two billion people, one-third of the global population, and nearly $\$ 65.5$ billion is lost annually due to forgone income from desertified cropland and rangelands (Dregne and Chou 1992, Arnalds and Archer 2000, Millenium Ecosystem Assessment 2005). And third, understanding the biological mechanisms that generate and maintain soil stability will aid in the prioritization of soil conservation and restoration efforts. For example, the majority of biological erosion control efforts stress the incorporation of plants (Toy et al. 2002). But in dryland ecosystems, measures to promote other organisms could also be beneficial. Untangling the contributions of soil organisms to soil stability is prerequisite to the preservation and restoration of soil resources.

We studied plant, BSC, and AM fungal communities of semiarid Artemisia shrubland ecosystems of the southern Colorado Plateau in the southwestern United States. Mean annual precipitation in this region is generally $<450 \mathrm{~mm}$, and plant communities are categorized as part of the larger Great Basin Conifer Woodland biotic community type, one of the most extensive types of vegetation found in the southwestern United States (Brown 1994). The Colorado Plateau region contains great edaphic heterogeneity, and erodibility of these soils can vary depending on proximity to biological soil stabilizing agents. For instance, soils with an intact BSC community and no plant cover, such as those of undisturbed shrub interspaces, can have highly stable soil surfaces (the top $1 \mathrm{~cm}$ ), but unstable soils as few as $1-2 \mathrm{~cm}$ below the surface. In contrast, subsurface soils that contain plant roots and AM fungal hyphae, such as those found underneath shrub canopies, can be highly resistant to erosion (V. B. Chaudhary, personal observation). A major source of soil disturbance in the Colorado Plateau region is livestock production; few areas have escaped cattle grazing, and it is currently permitted in numerous parks, monuments, and recreation areas. In an effort to determine early warning signs of rangeland degradation, several land management agencies initiated a program to qualitatively and quantitatively assess rangeland health using indicators of soil stability, hydrologic function, and biotic integrity (Pellant et al. 2000). Soil stability at nearly 500 sites across the southern Colorado Plateau was measured, making it an excellent region in which to study the relationships between soil stability and the dominant organisms of semiarid shrublands.

\section{Goals and questions}

The purpose of this study was to address the following overarching research question: How do plants, BSCs, and AM fungi differ in their contributions to soil stability in semiarid shrublands? To this end we utilized a multivariate modeling technique to examine plants, BSCs, and AM fungi as a system of interrelated variables. Because these major biological components of drylands likely interact in natural systems, we sought to investigate the direct and indirect effects of these interactions on soil stability as well as on each other (note that direct and indirect effects are understood with reference to direct and indirect pathways in models). We first formulated a conceptual model based on information from previous research and ecological knowledge of the system and used that to guide the specification of a priori structural equation models (Grace and Bollen 2008). We then evaluated the structural equation models using our empirical data. From this analysis process we obtained estimates of the strength of all hypothesized relationships present in the model.

Fig. 2 shows the a priori conceptual model we formulated to represent hypothesized effects of plants, BSCs, and AM fungi on soil stability. Dashed boxes represent conceptual variables without regard for precisely how they would be specified in statistical models. Arrows represent hypothesized mechanistic processes associated with various pathways (summarized in Table 1). Several causal pathways that have been shown to exist; for example, feedbacks between AM fungal abundance and plant cover and BSC cover and plant cover (Bever 1994, Belnap et al. 2001), were omitted from the conceptual model because they likely operate on different time scales than those examined in this study. Paths $\mathrm{J} 1-\mathrm{J} 3$ and $\mathrm{K}$ were included in the model to account for variation caused by abiotic differences among sites and incorporate sampling design structure.

Related to the ideas represented in our conceptual model, we sought to address two main research questions: (1) What are the direct and indirect contributions of plants, BSCs, and AM fungi to soil stability and how do they compare in strength to one another? Further, do our predictors explain a substantial proportion of the observed variation in soil stability? (2) Do the biological contributions to soil stability differ between surface and subsurface soils? Here we hypothesized that BSCs play a primary role in surface soil stability, while plants and AM fungi play a more important role in subsurface stability.

\section{Methods}

\section{Sampling design}

To examine the biological contributions to soil stability in a semiarid shrubland landscape, we sampled 




FIG. 2. A priori conceptual model of hypothesized causal relationships between major biotic and abiotic components of semiarid shrublands and soil stability. Dashed boxes represent constructs of interest without regard for precisely how they are measured. Proposed mechanisms for each path (letters A-K) are described in Table 1.

soil across a gradient of soil stability levels within four soil (Bowker and Belnap 2008) and climatic regions in the 769000-ha Grand Staircase-Escalante National Monument (GSENM) in southern Utah, USA $\left(37^{\circ} 24^{\prime}\right.$ N, $111^{\circ} 41^{\prime} \mathrm{W}$; Fig. 1). Sites representing three surface soil stability levels (low, medium, or high) were selected from within each of the four regions for a total of 12 sites. Regions were roughly 5000 ha in size, and sites were 0.5 ha in size. The four soil and climatic regions were located near the towns of Big Water, Cannonville,
Escalante, and Boulder. Soil, climate, and vegetation characteristics of each region are summarized in Appendix A. The average surface (top $1 \mathrm{~cm}$ ) and subsurface (15 cm deep) soil stability rating of each site was previously determined in the Bureau of Land Management's extensive rangeland health assessment (Pellant et al. 2000) using an in-field aggregate stability test (Herrick et al. 2001). In this procedure, soil peds are assigned a rank score between $1 \quad(<10 \%$ structural integrity after wet sieving) and $6(>75 \%$ structural

TABle 1. Pathways and presumed processes associated with a priori model (see Fig. 2).

\begin{tabular}{|c|c|c|c|}
\hline Pathway & $\begin{array}{l}\text { Alpha } \\
\text { code }\end{array}$ & Interpretation & Mechanistic examples \\
\hline Plant cover $\rightarrow$ soil stability & A & $\begin{array}{l}\text { influence of plant cover on soil stability } \\
\text { independent of effects mediated } \\
\text { indirectly by soil organic matter, AM } \\
\text { fungi, or BSCs }\end{array}$ & $\begin{array}{l}\text { dampening of wind and water erosive } \\
\text { forces, root enmeshment of soil } \\
\text { macroaggregates }\end{array}$ \\
\hline $\begin{array}{l}\text { Plant cover } \rightarrow \\
\quad \text { soil organic matter }\end{array}$ & B & $\begin{array}{l}\text { contribution of plants to soil organic } \\
\text { matter accumulation independent of } \\
\text { any influence through AM fungi }\end{array}$ & root contributions to soil organic matter \\
\hline $\begin{array}{l}\text { Soil organic matter } \rightarrow \\
\quad \text { soil stability }\end{array}$ & $\mathrm{C}$ & $\begin{array}{l}\text { contribution of soil organic matter to soil } \\
\text { stability }\end{array}$ & $\begin{array}{l}\text { organic matter binding to clay particles } \\
\text { to produce aggregates }\end{array}$ \\
\hline AM fungi $\rightarrow$ soil stability & $\mathrm{D}$ & $\begin{array}{l}\text { separate contribution of AM fungi to soil } \\
\text { stability }\end{array}$ & $\begin{array}{l}\text { hyphal enmeshment of soil } \\
\text { microaggregates, glomalin production }\end{array}$ \\
\hline $\begin{array}{l}\text { AM fungi } \rightarrow \\
\text { soil organic matter }\end{array}$ & $\mathrm{E}$ & $\begin{array}{l}\text { contribution of AM fungi to soil organic } \\
\text { matter accumulation }\end{array}$ & $\begin{array}{l}\text { spore and hyphal contributions to soil } \\
\text { organic matter }\end{array}$ \\
\hline BSC $\rightarrow$ soil stability & $\mathrm{F}$ & $\begin{array}{l}\text { independent contribution of biological } \\
\text { soil crusts to soil stability }\end{array}$ & $\begin{array}{l}\text { soil particle adhesion by cyanobacterial } \\
\text { filaments, increased water infiltration }\end{array}$ \\
\hline Plant cover $\rightarrow$ BSC & G & $\begin{array}{l}\text { influence of plants on biological soil } \\
\text { crusts }\end{array}$ & $\begin{array}{l}\text { reduction of BSC available habitat by } \\
\text { litterfall and shading }\end{array}$ \\
\hline Plant cover $\rightarrow$ AM fungi & $\mathrm{H}$ & influence of plants on AM fungi & $\begin{array}{l}\text { obligate biotrophy: AM fungi cannot } \\
\text { live without plants }\end{array}$ \\
\hline Region $\rightarrow$ BSC & $\mathrm{J} 1$ & $\begin{array}{l}\text { regional differences in biological soil crust } \\
\text { cover }\end{array}$ & BSC cover varies by climate \\
\hline Region $\rightarrow$ plant cover & $\mathrm{J} 2$ & regional differences in plant cover & plant cover varies by climate \\
\hline Region $\rightarrow$ AM fungi & $\mathrm{J} 3$ & $\begin{array}{l}\text { regional differences in AM fungi } \\
\text { abundance }\end{array}$ & AM fungal abundance varies by climate \\
\hline Microsite $\rightarrow$ plant cover & $\mathrm{K}$ & microsite differences in plant cover & $\begin{array}{l}\text { more plant cover near shrub canopies } \\
\text { than interspaces }\end{array}$ \\
\hline
\end{tabular}

Notes: All pathways represent the influence of a factor independent from other influences in the model. 
integrity after wet sieving). These aggregate stability scores have been shown to be curvilinearly correlated to the percentage of aggregate stability traditionally measured in the laboratory with mechanical wet sieving (Herrick et al. 2001). All soil sampling sites were located using GPS coordinates, and Rangeland Health Assessment stability ratings were confirmed by conducting additional slake tests at the time of soil sampling. No difference was detected between our slake measurements and those of the earlier Rangeland Health Assessment Protocol (Wilcoxon signed-rank test, $P=0.548$ ).

To account for microsite heterogeneity commonly present in arid ecosystems, sampling was stratified to include soil from both underneath shrub islands (referred to as "canopy") and interspaces between shrub islands (referred to as "interspace"). At each site, 18 soil samples were collected at a depth of $15 \mathrm{~cm}$, half from the rhizosphere of randomly selected shrubs and the other half from the adjacent interspaces. In entirety, the study contained 216 observations collected from a total of 12 sites. To hold the sampling location consistent, canopy samples were collected from the north side of the shrub and interspace samples were located at least $1 \mathrm{~m}$ away from any shrub. Because AM fungi have been shown to exhibit host specificity, shrub genus was held constant. Artemisia tridentata plants were sampled in the Boulder, Cannonville, and Escalante regions, while Artemisia filifolia plants were sampled in the Big Water region. Artemisia was chosen as the target genus because it is the dominant plant species at all sites and has a wide distribution across the western United States. Soil samples were collected in May 2004, air-dried, and stored at $4^{\circ} \mathrm{C}$ until processed.

\section{Plant, BSC, and AM fungal assessment}

At each sample location, plant cover and BSC cover were visually quantified within a $1-\mathrm{m}^{2}$ quadrat. Cover of each plant species within a plot was individually measured, but later summed for analysis of total plant cover. Roots were not present at our soil sampling depth of $15 \mathrm{~cm}$; therefore, we assumed plant cover to be a reasonable proxy for root biomass. Total BSC cover was quantified by the presence of any BSC community component, including cyanobacteria, lichens, or bryophytes. Species most often encountered were the cyanobacterium Microcoleus vaginatus and the moss Syntrichia caninervis.

Because an optimal technique for measuring AM fungal abundance at the GSENM has not been determined, we quantified AM fungi using four different methods: a mycorrhizal infection potential (MIP) bioassay, hyphal density, GRSP concentration, and spore abundance. The MIP bioassay is a comparative measure of viable AM fungal propagules, where root colonization of bait plants is assessed as a measure of living, infective mycorrhizal propagules present in the soil (Moorman and Reeves 1979, Jasper et al. 1989). In July 2004, Zea mays bait plants were grown in $150 \mathrm{~mL}$ of each soil sample in $3.8 \mathrm{~cm}$ diameter Conetainers (Stuewe and Sons, Corvallis, Oregon, USA) in a greenhouse. After 6 weeks, plants were harvested, and a 0.25 -g root subsample was cleared, stained, and examined using a compound microscope (200× magnification) for the presence of AM fungal structures (McGonigle et al. 1990, Vierheilig et al. 1998).

Hyphal density and GRSP concentration were assessed because of their suspected physical and chemical contributions to soil structure (Miller and Jastrow 2000). Hyphal density was quantified by agitating $5 \mathrm{~g}$ of soil in a blender, siphoning the suspension with a pipette, and then collecting hyphal fragments on a membrane filter (modified from Jakobsen et al. 1992). Hyphae were preserved on permanent slides, examined with a compound microscope for morphology that is characteristic of AM fungi (e.g., absence of regular septae), and length per gram of soil was calculated using the grid-line intersection method (Tennant 1975). Two different fractions of GRSP, easily extractable Bradfordreactive soil protein (EE-BRSP) and total BRSP, were quantified (Rillig 2004). Protein concentration of each sample was determined using the Bradford colorimetric protein assay (Bradford 1976, Wright and Upadhyaya 1996).

Spore abundance was quantified as another potential indicator of AM fungal abundance and was determined by extracting spores from a 30 -g subsample of soil by wet-sieving and centrifuging through a sucrose density gradient (Gerdemann and Nicholson 1963, McKenney and Lindsey 1987). Spores were collected by suction filtration and mounted onto glass microscope slides for enumeration using a compound microscope (200× magnification).

\section{Soil properties}

Six abiotic soil characteristics were measured primarily to explore their potential relationships with plants, BSCs, and AM fungi, and secondarily to explore their relationships with soil stability. Soil organic matter was measured by percentage of mass loss after ashing for 24 $\mathrm{h}$ at $550^{\circ} \mathrm{C}$. Inorganic carbon was removed from soil samples prior to ashing using a method adapted from Harris et al. (2001) by washing soil samples with $6 \mathrm{~mol} / \mathrm{L}$ $\mathrm{HCl}$ to evolve carbonates. Soil $\mathrm{pH}$ and electrical conductivity (EC) were determined by creating a soilwater slurry and measuring with a glass electrode $\mathrm{pH}$ meter (Corning Incorporated, Corning, New York, USA) and a table-top EC meter (YSI, Yellow Springs, Ohio, USA). Soil ammonium $\left(\mathrm{NH}_{4}{ }^{+}\right)$and nitrate $\left(\mathrm{NO}_{3}{ }^{-}\right)$concentrations were measured using $\mathrm{KCl}$ extraction, and available phosphorus $(\mathrm{P})$ concentration was analyzed using the Melich III extraction procedure (Mehlich 1984).

\section{Analysis of data}

We examined the relationships between soil stability, plants, BSCs, AM fungi, and soil properties by 
conducting pairwise correlations between all response variables and comparing the strength of these relationships using Pearson's correlation coefficients $(r)$. Analyses were performed for a total of 216 observations. All correlation analyses were performed using JMP 4.0 Statistical Package (SAS Institute 2000).

To analyze our data as a system of interrelated variables, we evaluated our a priori model of the causal relationships among agents of soil stabilization using structural equation modeling (SEM). SEM is a method of specifying and evaluating complex hypotheses involving multiple pathways of influence operating in systems (Bollen 1989, Shipley 2000, Grace 2006). It contrasts most directly with univariate models, which are primarily suited for selection of sets of predictors and for the summarization of net effects. SEM can be performed using either maximum likelihood or Bayesian methods (Lee 2007). SEM involves both the estimation of parameters and an evaluation of data-model consistency. By comparing model-implied covariance structure with the actual covariance structure in data, an evaluation of overall model fit is achieved (typically using a model $\chi^{2}$ test). Such evaluations of overall model fit permit not only an assessment of specified pathways, but also detection of unanticipated relationships.

We used the following protocol: first, we created an a priori conceptual model of presumed causal relationships (Fig. 2). We considered surface and subsurface stability separately in two parallel models. Working in a backward direction from hypothesized effect to hypothesized cause, we constructed the model in two primary phases. The process of building models in multiple phases is a useful strategy to manage model complexity and focus on the most important relationships (Grace and Keeley 2006). In the first phase, we constructed models containing all variables proposed to have a direct influence upon soil stability and their proposed interrelationships. We evaluated the fit of these models using the maximum likelihood $\chi^{2}$ goodness-of-fit test, Joreskög's goodness of fit index (GFI), and the root mean square error of approximation (RMSEA) index. Rules of thumb for desired values for these indices are high $P$ values for the $\chi^{2}$ test, close to 1 for Joreskög's GFI, and close to 0 for RMSEA. Using multiple goodness-of-fit indices is generally recommended in SEM, particularly when sample size is large $(>100$ observations; Grace 2006). Based on the results of goodness-of-fit tests, we decided which variables were the most informative and retained them, excluding less predictive measures of our concepts. At this stage of the process we also resolved directionality of primary causal influences between pairs of variables that could conceivably have a feedback relationship by comparing alternative models involving reciprocal relationships and choosing the best-fitting model. While many parts of an a priori model are generally confirmed, a satisfactory goodness of fit is often not obtained initially, and rather than stop at the confirmatory stage, it is more informative to engage in exploratory analyses. Thus, after initial evaluations, we conservatively used modification indices (single algorithm-provided changes in the model that can result in better fit; Jöreskog and Sörbom 1984) when justifiable on theoretical grounds or past knowledge. Recommended changes were considered one at a time until a satisfactory overall fit was obtained. When this portion of the model had achieved a satisfactory fit, we began the second phase of model construction and introduced abiotic variables. We repeated the above protocol, discarding uninformative variables. Uninformative weak pathways were those that, when removed, did not alter the fit of the model. Again we used modification indices conservatively until we arrived at a model structure with satisfactory fit. It is important to note that in the $\chi^{2}$ test, low $P$ values indicate lack of fit and poor empirical support for the multiple causal hypotheses in the model. At this point, we grouped AM fungal variables together into a composite variable (Grace and Bollen 2008), a useful way to observe the combined effects of conceptually linked variables. Finally, we removed uninformative weak pathways for simplification and retested the resultant final model. Final models generated in this way are considered to be provisional until confirmed by being used as a priori models in future studies. All SEM analyses were performed using AMOS Software Version 5 (SPSS 2006).

\section{RESUlts}

\section{Relationships between soil stability and plants, BSCs,} and $A M$ fung $i$

Soil surface stability and subsurface stability were weakly correlated with each other $(r=0.39)$ and with many biotic and abiotic variables (Table 2). Surface stability was weakly positively correlated with EE-BRSP concentration $(r=0.34)$, spore abundance $(r=0.27)$, plant cover $(r=0.23)$, hyphal density $(r=0.21)$, BSC cover $(r=0.19)$, and percentage of MIP colonization $(r=$ $0.13)$. Surface stability was weakly negatively correlated with soil $\mathrm{NH}_{4}(r=-0.19)$. Subsurface stability was weakly positively correlated with plant cover $(r=0.47)$, percentage of organic matter $(r=0.47)$, percentage of MIP colonization $(r=0.45)$, electrical conductivity $(r=$ $0.42)$, hyphal density $(r=0.41)$, EE-BRSP concentration $(r=0.34)$, and spore abundance $(r=0.18)$. Subsurface stability was negatively correlated with BSC cover $(r=$ $-0.36)$ and $\mathrm{NH}_{4}(r=-0.25)$. Means of all AM fungal variables, including patterns in variation at several spatial scales are presented in another manuscript (V. Bala Chaudhary, N. C. Johnson, T. E. O'Dell, and M. C. Rillig, unpublished manuscript).

\section{Surface stability model}

Results were found to be congruent with our hypothesized conceptual model of the biotic and abiotic factors that influence surface soil stability in semiarid shrublands. Results are summarized in Fig. 3A. Note 
TABLE 2. Pairwise correlations between surface and subsurface stability and all biotic and abiotic measured variables.

\begin{tabular}{|c|c|c|c|c|c|c|c|c|}
\hline & $\begin{array}{l}\text { Surface } \\
\text { stability }\end{array}$ & $\begin{array}{l}\text { Subsurface } \\
\text { stability }\end{array}$ & $\begin{array}{c}\text { Plant } \\
\text { cover }(\%)\end{array}$ & $\begin{array}{c}\text { BSC } \\
\text { cover }(\%)\end{array}$ & $\begin{array}{c}\text { Hyphal } \\
\text { density }(\mathrm{m} / \mathrm{g})\end{array}$ & $\begin{array}{c}\text { Spore } \\
\text { abundance }\end{array}$ & $\begin{array}{c}\text { EE-BRSP } \\
(\mu \mathrm{g} / \mathrm{g})\end{array}$ & $\begin{array}{c}\text { MIP colonization } \\
(\%)\end{array}$ \\
\hline Surface stability & 1.00 & & & & & & & \\
\hline Subsurface stability & $0.39^{*}$ & 1.00 & & & & & & \\
\hline Plant cover $(\%)$ & $0.23^{*}$ & $0.47 *$ & 1.00 & & & & & \\
\hline BSC cover $(\%)$ & $0.19^{*}$ & $-0.36^{*}$ & $-0.62^{*}$ & 1.00 & & & & \\
\hline Hyphal density (m/g) & $0.21 *$ & $0.41 *$ & 0.10 & $-0.19^{*}$ & 1.00 & & & \\
\hline Spore abundance & $0.27 *$ & $0.18^{*}$ & $0.41 *$ & $-0.18^{*}$ & $0.18^{*}$ & 1.00 & & \\
\hline EE-BRSP $(\mu \mathrm{g} / \mathrm{g})$ & $0.34 *$ & $0.34 *$ & $0.51 *$ & $-0.28 *$ & $0.29 *$ & $0.65^{*}$ & 1.00 & \\
\hline MIP colonization (\%) & $0.13^{*}$ & $0.45^{*}$ & 0.06 & -0.09 & $0.48 *$ & 0.01 & 0.06 & 1.00 \\
\hline Organic matter $(\%)$ & 0.11 & $0.47 *$ & 0.11 & $-0.33^{*}$ & $0.73^{*}$ & $0.29 *$ & $0.40^{*}$ & $0.43 *$ \\
\hline $\mathrm{EC}(\mu \mathrm{S})$ & 0.02 & $0.42 *$ & $0.15^{*}$ & $-0.38^{*}$ & $0.51^{*}$ & 0.12 & $0.23^{*}$ & $0.32 *$ \\
\hline $\mathrm{pH}$ & -0.05 & 0.11 & 0.03 & $-0.14 *$ & $0.16^{*}$ & $-0.16^{*}$ & $-0.21^{*}$ & 0.04 \\
\hline $\mathrm{P}(\mathrm{ppm})$ & 0.10 & -0.05 & $0.27 *$ & $-0.21^{*}$ & 0.12 & $0.48^{*}$ & $0.70^{*}$ & $-0.13 *$ \\
\hline $\mathrm{NH}_{4}^{+}(\mathrm{ppm})$ & $-0.19^{*}$ & $-0.25^{*}$ & -0.01 & -0.11 & -0.12 & -0.06 & -0.02 & $-0.13 *$ \\
\hline $\mathrm{NO}_{3}^{-}(\mathrm{ppm})$ & -0.12 & 0.07 & 0.10 & $-0.28 *$ & 0.13 & $0.23 *$ & $0.47 *$ & -0.01 \\
\hline
\end{tabular}

Notes: Values indicate Pearson correlation coefficients $(r)$.

$* P \leq 0.05$.

that mention of direct and indirect effects is understood to be within the context of direct and indirect paths in the models. Thirty-five percent of the variation in soil surface stability was explained by this model. Biological soil crust cover had the strongest direct effect on surface soil stability (0.60), followed by plant cover (0.44), AM fungal abundance (0.37), and then soil/climate region (0.21). In addition to direct contributions, plant cover influenced surface soil stability indirectly in two ways. First, plant cover appeared to indirectly hinder surface soil stability by having a negative relationship with BSC cover, which in turn promotes surface stability. Second, plant cover appeared to indirectly encourage surface soil stability by having a positive relationship with AM fungal abundance, which in turn promotes surface stability in the model. The total influence of plant cover on surface soil stability, including direct and indirect effects, was strongly positive (0.49; Table 3$)$. The variables that best explained AM fungal abundance in the surface stability model were EE-BRSP concentration and hyphal density. Both EE-BRSP concentration (0.84) and hyphal density (0.36) strongly contributed to the AM fungal abundance composite variable. AM fungal abundance had a strong positive relationship with surface soil stability even though AM fungi are not thought to exist in the top few millimeters of soil. A nondirectional residual correlation (0.19) between BSC cover and AM fungal abundance was found.

In contrast to our hypothesized model, rhizosphere soil organic matter content did not explain surface soil stability and was therefore omitted from the final model. Model results imply that microsite positively influenced plant cover (0.87), but negatively influenced BSC cover $(-0.43)$. In other words, samples from underneath shrub canopies had higher plant abundance, but lower BSC cover than samples from interspaces. Furthermore, microsite had no direct influence on surface soil stability. In addition to directly influencing surface soil stability, soil/climate region strongly influenced BSC cover and AM fungal abundance, indicating that these biotic variables vary considerably across our four sampling regions.

\section{Subsurface stability model}

The data were congruent with our hypothesized causal model of the biotic and abiotic factors that influence subsurface soil stability in semiarid shrublands (Fig. 3B). Fifty-four percent of the variation in subsurface soil stability was explained by this model. Plant cover had the strongest direct influence on subsurface stability (0.42) followed by AM fungal abundance (0.32) and soil/climate region (0.31). Results indicate that plant cover positively affected subsurface stability both directly and indirectly through the promotion of AM fungal abundance. The variables that best explained AM fungal abundance in the subsurface stability model were percentage of MIP colonization, total BRSP, and hyphal density. Percentage of MIP (0.68), total BRSP (0.64), and hyphal density (-0.11) all contributed to the AM fungal composite variable for subsurface stability.

In contrast to our hypothesized model, rhizosphere soil organic matter content and BSC cover did not have strong direct effects on subsurface soil stability and were therefore omitted from the final model. Although soil organic matter content was positively correlated with subsurface stability (Table 2), our model indicates that this does not appear to be a causative relationship. Instead, other factors that are also correlated with organic matter, such as hyphal density, are likely affecting subsurface stability. Microsite is positively related to plant cover, such that samples from underneath shrub canopies had higher plant abundance. Furthermore, microsite had no direct path to subsurface soil stability. In addition to directly relating to subsurface soil stability, soil/climate region is strongly related to AM fungal abundance, indicating that AM fungi vary considerably across our four sampling regions. 
TABLE 2. Extended.

\begin{tabular}{llllll}
\hline \hline $\begin{array}{c}\text { Organic } \\
\text { matter }(\%)\end{array}$ & $\begin{array}{c}\mathrm{EC} \\
(\mu \mathrm{S})\end{array}$ & $\mathrm{pH}$ & $\mathrm{P}(\mathrm{ppm})$ & $\begin{array}{l}\mathrm{NH}_{4}^{+} \\
(\mathrm{ppm})\end{array}$ & $\begin{array}{l}\mathrm{NO}_{3}^{-} \\
(\mathrm{ppm})\end{array}$ \\
\hline
\end{tabular}

\begin{tabular}{lccccc}
1.00 & & & & & \\
$0.70^{*}$ & 1.00 & & & & \\
0.08 & -0.06 & 1.00 & & & \\
$0.28^{*}$ & $0.17^{*}$ & $-0.28^{*}$ & 1.00 & & \\
-0.02 & 0.13 & -0.04 & $0.13^{*}$ & 1.00 & \\
$0.34^{*}$ & $0.39^{*}$ & -0.09 & $0.47^{*}$ & $0.32^{*}$ & 1.00 \\
\hline
\end{tabular}

\section{Discussion}

To our knowledge, this is the first study to use SEM to understand the relative influences that major biological components play in stabilizing soil at a landscape scale in semiarid ecosystems. As such, our findings should be considered to be provisional and in need of subsequent testing. Previous studies have used SEM to evaluate the relative contributions of AM fungi and plants to soil stability, but these studies were either conducted in mesic environments or experimental plots at a single site (Jastrow et al. 1998, Rillig et al. 2002). Through our analyses, we explored the many direct and indirect influences that plants, BSCs, and AM fungi may have on soil stability, as well as on each other. The role of plants in the formation and maintenance of soil stability is relatively well established; this study highlights the important role that soil microbial communities, in particular BSCs and AM fungi, can also play in this important ecosystem service. Our results provide evidence that these three major ecosystem players work in concert to generate and maintain soil stability in arid lands. We do not argue that alternative plausible causal schemes do not exist. Instead, we can only claim that our models (and, therefore, the results) are consistent with the data. Furthermore, although our study focused on commonly distributed Artemisia shrublands, other prevalent shrubs of semiarid environments (e.g., Atriplex, Sarcobatus, Grayia) vary in their dependency on AM fungi (Miller 1979, Call and McKell 1985). If certain environments lack plants that form AM associations, AM fungi would be less prevalent and the biological contributions to soil stability could differ from those presented in our models.

Our a priori hypothesized, causal model of factors that contribute to soil stability in semiarid shrublands (Fig. 2) was supported by the data after incorporating only minor adjustments. In the case of surface stability, $35 \%$ of the variation was explained; for subsurface stability, $54 \%$ of the variation was explained. In both models, the strongest contributions to soil stability were made by biological components of the system. It is important to note that certain abiotic properties that strongly contribute to soil stability, such as texture and calcium carbonate or gypsum content (Tisdall and Oades 1982), were not included in our models because the focus of this study was on the biological contributions to the stability and erodibility of soils. It is possible that the inclusion of specific abiotic variables could have increased the proportion of variation explained by both models. The composite variable "soil/climate region" included in both models directly influenced soil stability, but the contribution was weak compared to the contributions of the soil organisms. This variable likely accounted for landscape-scale variation in soil abiotic variables, but not site or microsite variation. Across regions, average calcium carbonate content ranged from $3 \%$ to $10 \%$ in Big Water, $1 \%$ to $25 \%$ in Escalante, $1 \%$ to $5 \%$ in Cannonville, and $0 \%$ to $2 \%$ in Boulder. These values are considerably lower than reported (mean $71 \%$ ) for studies that show a strong correlation between calcium carbonate content and soil stability (Rillig et al. 2003).

In both the surface and subsurface models, no direct effect of microsite on soil stability was detected. This indicates that the soil stability mechanisms confirmed by our models do not differ substantially between shrub islands and interspaces. These results do not contradict work that suggests that interspace soils are more susceptible to erosive forces than shrub canopy soils (Abrahams et al. 1995, Schlesinger et al. 1996). Instead, we suggest that even in interspaces that appear to be relatively devoid of life in arid environments, biotic communities provide vital ecosystems services, such as the generation and maintenance of soil stability. Belowground, roots and AM fungal hyphae extend between plant canopies and stabilize interspace soil.

\section{Mechanisms that generate surface stability}

On the soil surface, BSC communities made the largest direct contribution to soil stability. It was anticipated that the BSC contribution to surface stability would be large because at high stability sites BSC communities comprised an average of $67 \%$ of interspace cover. BSCs promote soil surface stability by increasing water infiltration, enhancing soil microstructure, improving soil fertility (Belnap and Gardner 1993), and improving surface soil resistance to rain impact (Eldridge and Kinnell 1997). However, it was not expected that the relative influence of BSCs on surface stability would be much larger than that of plant cover as indicated by the model. Our study underscores the importance of BSCs in the creation and maintenance of soil stability in dryland ecosystems.

Plant cover had the second strongest direct effect on surface soil stability. Plant cover likely directly influences surface stability by acting as a wind break, a rainfall break, and by adding litterfall, which can improve surface resistance to rain impact. The model also 



FIG. 3. Final structural equation models (SEMs) of the biotic and abiotic contributions to (A) surface and (B) subsurface soil stability in semiarid shrublands. Values associated with arrows (and line width) relate to path strength. Rectangles represent individual measured variables, while hexagons represent composite effects. Values in italics above rectangles indicate the proportion of variation explained for the given measured variable. In the surface stability model (panel A), the superscript letter "a" refers to influences on hyphal density, and the superscript " $b$ " refers to influences on easily extractable Bradford-reactive soil protein (EE-BRSP). Bootstrap fit $P=0.69, \chi^{2}=3.96, P=0.68, \chi^{2} / \mathrm{df}=0.66$, GFI $=0.996$, and RMSEA $=0.0$. In the subsurface stability model (panel B), the superscript letter "a" refers to influences on hyphal density, the superscript "b" refers to influences on total BRSP, and the superscript "c" refers to influences on viable propagules. Bootstrap fit $P=0.75, \chi^{2}=4.088, P=0.665, \chi^{2} / \mathrm{df}=$ $0.681, \mathrm{GFI}=0.996$, and RMSEA $=0.0$.

highlights that, by having a negative effect on BSC cover, plant cover may have an indirect antagonistic influence on surface stability. On the other hand, plant cover indirectly promoted surface stability by having a positive effect on AM fungal abundance. Such contradictory effects are often masked when examining a simple bivariate correlation between two variables, which could explain the relatively low bivariate correlation between plant cover and soil surface stability $(r=$ 0.23 ; Table 2). Even with these antagonistic effects, the total effect of plant cover on surface stability was strongly positive (Table 3 ), confirming the important role of plant communities in creating and maintaining soil surface stability.

Interestingly, AM fungi make a substantial contribution to surface stability, even though they are not generally thought to be abundant in the top few millimeters of the soil profile. Schwab and Reeves (1981) showed that the amount of viable AM fungal propagules was high in the top $10 \mathrm{~cm}$ of soil in a

TABLE 3. Summary of standardized direct and total effects of biotic and abiotic factors on surface and subsurface soil stability.

\begin{tabular}{lccccc}
\hline \hline \multirow{2}{*}{ Variable } & \multicolumn{2}{c}{ Surface } & stability & & \multicolumn{2}{c}{ Subsurface stability } \\
\cline { 2 - 3 } \cline { 5 - 6 } \cline { 5 - 6 } & Direct & Total & & Direct & Total \\
\hline BSC cover & 0.60 & 0.60 & & $\ldots$ & $\ldots$ \\
Plant cover & 0.44 & 0.49 & & 0.42 & 0.42 \\
AM fungal abundance & 0.38 & 0.38 & & 0.32 & 0.32 \\
Soil/climate region & 0.21 & 0.38 & & 0.31 & 0.20 \\
\hline
\end{tabular}

Note: Ellipses indicate no influence of BSCs on subsurface stability. 
semiarid sagebrush community, but did not examine AM fungal abundance at a finer scale. In arid ecosystems, soil moisture and nutrients are patchy and often concentrated in "islands of fertility" (Schlesinger et al. 1996) or BSC layers. It is possible that AM fungal hyphae explore soil surfaces comprised of BSCs to mine nutrients and water, leaving behind recalcitrant hyphal filaments and glomalin, which promote surface stability. We are aware of no studies examining the abundance of AM fungi within BSC layers, although some studies have indirectly studied interactions between AM fungi and BSCs in reference to plant growth and nitrogen cycling (Hawkes 2003, Pendleton et al. 2003). More research is needed to examine the nature and mechanisms of interactions between AM fungi and BSCs and their impacts on the formation and maintenance of soil stability.

Although our model was supported by the data, only $35 \%$ of the variation in soil stability was explained in the surface stability SEM. This could indicate two things: (1) additional unmeasured factors contribute to soil stabilization or (2) the soil stabilizing properties of the two factors with the strongest direct influences on surface stability, plants and BSCs, were not measured appropriately. First, other organisms such as bacteria, non-AM fungi, soil invertebrates, and cattle influence soil stability (Oades 1984, Friedel 1991, Tisdall 1994). Incorporating measures of other soil organisms or an index of grazing pressure could improve the amount of variation explained by the model. Second, plants and BSCs were quantified using percent cover, which is probably not the best metric to assess the potential for BSC or plant communities to stabilize soil. Instead, densities of cyanobacterial filaments, fine roots $(0.2-1.0$ $\mathrm{mm}$ diameter $)$, and very fine $(<0.2 \mathrm{~mm}$ diameter $)$ root lengths may be better indicators of the biological soil stabilizing agents. Incorporating stability-related measurements of plants and BSCs could boost the overall $R^{2}$ values in both models.

\section{Mechanisms that generate subsurface stability}

Plants made the strongest total contribution to subsurface stability. Plant cover had both the largest total contribution and the strongest direct influence on subsurface stability, indicating that mechanisms such as enmeshment of soil particles by roots and root exudates are driving the creation and maintenance of soil stability. Plant cover also indirectly promoted subsurface stability by positively affecting AM fungal abundance. Unlike the surface stability model, there was no strong antagonistic relationship between plant cover and BSCs below the surface of the soil, and thus, the relationship between plant cover and subsurface stability is only positive. In this case, the relationship is not masked by two opposing forces, which could explain the stronger bivariate correlation between plant cover and subsurface stability ( $r=0.47$; Table 2$)$. Although BSCs were found to have no direct influence on subsurface stability, they likely contribute to belowground soil stability at a greater temporal scale since intact soil surfaces can act as the first line of defense against erosive forces.

\section{Comparison with models from mesic systems}

Our soil stability models contained many similarities to a soil stability model constructed in a mesic ecosystem. Jastrow et al. (1998) used SEM in a restored tallgrass prairie in northern Illinois, USA, to examine the interacting biotic and abiotic contributions to subsurface stability. They examined the direct and indirect influences of plant root production, AM fungal hyphal density, organic matter, microbial biomass, and hot-water soluble carbohydrate carbon content on water stable soil aggregation. In their model, plants made the largest total contribution to soil stability, as was the case in our subsurface stability model. They also found that soil organic matter had a weak influence on aggregation. Furthermore, in the tallgrass prairie model, the strength of association between AM fungi and soil stability was similar to that found in our subsurface stability model: 0.38 in the tall grass prairie study vs. 0.32 in our semiarid shrublands. These results are striking considering that average hyphal density ranged from 16.9 to $45.4 \mathrm{~m} / \mathrm{cm}^{3}$ in the tall grass prairies and 0.27 to $7.80 \mathrm{~m} / \mathrm{cm}^{3}$ in our semiarid shrublands. This may indicate that even though the abundance of AM fungal hyphae is much lower in semiarid shrublands, the relative contribution of AM fungi to soil stability is similar.

In both the surface and subsurface models, the hypothesis that organic matter content directly influences soil stability (path C in Fig. 2) was not supported. We formulated this hypothesis because plants, AM fungi, and BSCs all contribute to soil organic matter pools, and it has been suggested that organic matter is important in generating soil structure and stability (Tisdall and Oades 1982). In our study, rhizosphere organic matter content did not predict soil stability in either the surface or subsurface models and was therefore omitted from the models. These results indicate that organic matter may not be an important driver of soil stability in arid and semiarid ecosystems. Instead, aboveground plant mechanisms of erosion prevention such as decreasing wind erosion, aeolian dust trapping, and decreasing splash erosion may be of particular importance in arid ecosystems compared to organic matter production. Indeed, it has been observed that the influence of organic matter on soil aggregation is related to the decomposability of the material (Tisdall and Oades 1982). In arid and semiarid regions, decomposition rates can be slow or rapid depending on climate patterns, evapotranspiration rates, latent heat flux, and the spatial heterogeneity of these factors (Schlesinger et al. 1990, Connin et al. 1997). On the Colorado Plateau, threshold levels of soil moisture and temperature dictate decomposition rates (Fernandez et al. 2006). Furthermore, organic matter content at our 
sites was very low (mean $1 \%$ by mass), and it is possible that a threshold amount of organic matter is necessary before it becomes an important player in the creation of soil structure and stability. Finally, it is possible that instead of directly contributing to soil stability, organic matter indirectly influences soil stability by providing habitat for soil-stabilizing organisms such as bacteria and fungi (Fenchel and Harrison 1976, St. John et al. 1983). This mechanism is corroborated by our data that showed a strong correlation between percentage of organic matter and AM fungal hyphal density $(r=0.73)$.

\section{System approach to erosion control}

The purpose of this study was not to identify which communities in arid ecosystems exert the strongest influence on soil stability and then suggest that management efforts focus on those communities alone. Instead, we demonstrated how plants, BSCs, and AM fungi work together to both directly and indirectly influence soil stability in semiarid shrublands. These communities also influence each other; in combination, they provide the vital ecosystem service of creating and maintaining soil stability. Soil aggregate stability is related to many parameters of soil health including soil fertility, biotic activity (Tidsall and Oades 1982), and resistance to erosion (Barthes and Roose 2002). We found that the types of biological communities that influence soil stability in dryland ecosystems differ from those of mesic systems. Erosion prediction equations such as the universal soil loss equation (USLE) and the revised universal soil loss equation (RUSLE) were developed in agroecosystems and are the dominant paradigm for understanding erosion in U.S. public lands (Spaeth et al. 2003). The RUSLE predicts soil loss due to erosion using measurements of climate erosivity, topography, soil erodibility, and land cover/management (Renard et al. 1991). Incorporating dryland specific information on soil organisms into the land cover/management component of RUSLE reveals that, when the intensity of erosive forces is constant, soil erosion in arid landscapes is primarily an outcome of land cover and management practices (Bowker et al. 2008). The formulation of dryland-specific erosion models is important as organisms in arid ecosystems experience unique selection pressures, potentially occupy different niches, and serve different ecosystem functions than those in mesic environments.

Constructing quantitative models that estimate the relative contributions of biotic and abiotic components to soil stability directly addresses the needs of practitioners who require information relating to best practices in erosion control. Often such efforts are restricted by limited resources such as time, money, and labor. Estimates of direct and total effects of biotic and abiotic factors generated by our models (Table 3 ) could be used to prioritize the allocation of resources in erosion control efforts. The relative strengths of these effects are then directly proportional to the amount of time, money, or effort spent on each component of the system to control erosion. By examining the proportional differences between the total effects that BSCs, plants, and AM fungi have on surface and subsurface stability we can estimate the relative amounts of resources that erosion control practitioners should spend on promoting each of these components of the system. Our models suggest that in erosion control practices conducted in semiarid shrublands of southern Utah, where the relative costs per unit output for plants, BSCs, and AM fungi are equal, practitioners should spend roughly $22 \%$ more resources on promoting BSCs than on promoting plants. Roughly $30 \%$ more resources should be spent on promoting plants than on promoting AM fungi.

This study highlights the need for system approaches in combating erosion, soil degradation, and arid-land desertification. Management efforts that contain no biotic components or incorporate only one type of organism (e.g., plants) fail to consider the long-term sustainability of soil stabilization and restoration. We predict a higher probability of long-term success in projects that recognize the vital role of soil microorganisms (and their many interactions) in the formation and maintenance of soil stability.

\section{ACKNOWLedgments}

This research was funded by the Cooperative Ecosystems Studies Program of the Bureau of Land Management (JSA990018). Additional funding was provided by an ARCS Foundation Fellowship to V. B. Chaudhary. Laboratory assistance was provided by T. Baker, M. Halldorson, T. Irving, and R. Rieder. We thank C. A. Gehring for helpful comments on an earlier draft and R. M. Miller for assistance during a priori model construction. The use of trade names is for descriptive purposes only and does not imply endorsement by the U.S. Government.

\section{Literature Cited}

Abrahams, A. D., A. J. Parsons, and J. Wainwright. 1995. Effects of vegetation change on interrill runoff and erosion, Walnut Gulch, southern Arizona. Geomorphology 13:37-48. Angers, D. A., and J. Caron. 1998. Plant induced changes in soil structure: processes and feedbacks. Biogeochemistry 42: 55-72.

Arnalds, O., and S. Archer. 2000. Introduction. Pages 1-4 in O. Arnalds and S. Archer, editors. Rangeland desertification. Kluwer Academic Publishers, Dordrecht, The Netherlands.

Barthes, B., and E. Roose. 2002. Aggregate stability as an indicator of soil susceptibility to runoff and erosion; validation at several levels. Catena 47:133-149.

Belnap, J., B. Budel, and O. L. Lange. 2001. Biological soil crusts: characteristics and distribution. Pages 3-30 in J. Belnap and O. L. Lange, editors. Biological soil crusts: structure, function, and management. Springer-Verlag, Berlin, Germany.

Belnap, J., and J. S. Gardner. 1993. Soil microstructure in soils of the Colorado Plateau: the role of the cyanobacteria Microcoleus vaginatus. Great Basin Naturalist 53:40- 47.

Belnap, J., C. V. Hawkes, and M. K. Firestone. 2003. Boundaries in miniature: two examples from soil. Bioscience 53:739-749.

Bever, J. D. 1994. Feedback between plants and their soil communities in an old field community. Ecology 75:19651977. 
Bollen, K. A. 1989. Structural equations with latent variables. John Wiley, New York, New York, USA.

Bowker, M. A., and J. Belnap. 2008. A simple classification of soil types as habitats of biological soil crusts on the Colorado Plateau, USA. Journal of Vegetation Science. [doi: 10.3170/ 2008-8-18454]

Bowker, M. A., J. Belnap, V. B. Chaudhary, and N. C. Johnson. 2008. Revisiting classic water erosion models in drylands: the strong impact of biological soil crusts. Soil Biology and Biochemistry 40:2309-2316.

Bradford, M. 1976. A rapid and sensitive method for the quantification of microgram quantities of protein utilizing the principle of protein-dye binding. Analytical Biochemistry 72:248-254.

Brown, D. E. 1994. Biotic communities - southwestern United States and northwestern Mexico. University of Utah Press, Salt Lake City, Utah, USA.

Call, C. A., and C. M. McKell. 1985. Endomycorrhizae enhance growth of shrub species in processed oil-shale and disturbed native soil. Journal of Range Management 38:258261.

Cardy, W. F. G. 2000. The United Nations databases on desertification. Pages 131-141 in O. Arnalds and S. Archer, editors. Rangeland desertification. Kluwer Academic Publishers, Dordrecht, The Netherlands.

Chaudhary, V. B. 2006. Functions of arbuscular mycorrhizal fungi at ecosystem and community scales in semiarid environments. Thesis. Northern Arizona University, Flagstaff, Arizona, USA.

Christensen, N. L., et al. 1996. The report of the Ecological Society of America Committee on the Scientific Basis for Ecosystem Management. Ecological Applications 6:665-691.

Connin, S. L., R. A. Virginia, and C. P. Chamberlain. 1997. Carbon isotopes reveal soil organic matter dynamics following arid land shrub expansion. Oecologia 110:374-386.

Diamond, J. 2005. Collapse: How societies choose to succeed or fail. Viking Press, New York, New York, USA.

Dregne, H. E. 1983. Desertification of arid lands. Hardwood Academic Publishers, New York, New York, USA.

Dregne, H. E., and N.-T. Chou. 1992. Global desertification dimensions and costs. Pages 249-281 in H. E. Dregne, editor. Degradation and restoration of arid lands. Lubbock, Texas Technical University, Lubbock, Texas, USA.

Driver, J. D., W. E. Holben, and M. C. Rillig. 2005. Characterization of glomalin as a hyphal wall component of arbuscular mycorrhizal fungi. Soil Biology and Biochemistry $37: 101-106$.

Eldridge, D. J., and I. A. Kinnell. 1997. Assessment of erosion rates from microphyte-dominated calcareous soils under rain-impacted flow. Australian Journal of Soil Research 35: 475-490.

Fenchel, T., and P. Harrison. 1976. The significance of bacterial grazing on mineral cycling for decomposition of particulate detritus. Pages 285-299 in J. M. Anderson and A. Macfadyen, editors. The role of terrestrial and aquatic organisms in decomposition processes. Blackwell Scientific, London, UK.

Fernandez, D. P., J. C. Neff, J. Belnap, and R. L. Reynolds. 2006. Soil respiration in the cold desert environment of the Colorado Plateau (USA): Abiotic regulators and thresholds. Biogeochemistry 78:247-265.

Friedel, M. H. 1991. Range condition assessment and the concept of thresholds: a viewpoint. Journal of Range Management 44:422-426.

Gadkar, V., and M. C. Rillig. 2006. The arbuscular mycorrhizal fungal protein glomalin is a putative homolog of heat shock protein 60. FEMS Microbiology Letters 263:93-101.

Gerdemann, J. W., and T. H. Nicolson. 1963. Spores of mycorrhizal endogone species extracted from soil by wet sieving and decanting. Transactions of the British Mycological Society 46:235-244.
Grace, J. B. 2006. Structural equation modeling and natural systems. Cambridge University Press, New York, New York, USA.

Grace, J. B., and K. A. Bollen. 2008. Representing general theoretical concepts in structural equation models: the role of composite variables. Environmental and Ecological Statistics 15:191-213.

Grace, J. B., and J. E. Keeley. 2006. A structural equation model analysis of postfire plant diversity in California shrublands. Ecological Applications 16:503-514.

Harris, D., W. R. Horwath, and C. van Kessel. 2001. Acid fumigation of soils to remove carbonates prior to total organic carbon or carbon-13 isotopic analysis. Soil Science Society of America Journal 64:1853-1856.

Hawkes, C. V. 2003. Nitrogen cycling mediated by biological soil crusts and arbuscular mycorrhizal fungi. Ecology 84: $1553-1562$.

Herrick, J. E., W. G. Whitford, A. G. de Soyza, J. W. Van Zee, K. M. Havstad, C. A. Seybold, and M. Walton. 2001. Field soil aggregate stability kit for soil quality and rangeland health evaluations. Catena 44:27-35.

Jakobsen, I., L. K. Abbott, and A. D. Robson. 1992. External hyphae of vesicular-arbuscular mycorrhizal fungi associated with Trifolium subterraneum L. 1. Spread of hyphae and phosphorus inflow into roots. New Phytologist 120:371-380.

Jasper, D. A., L. K. Abbott, and A. D. Robson. 1989. Soil disturbance reduces the infectivity of external hyphae of vesicular-arbuscular mycorrhizal fungi. New Phytologist 112: 93-99.

Jastrow, J. D., R. M. Miller, and J. Lussenhop. 1998. Contributions of interacting biological mechanisms to soil aggregate stabilization in restored prairie. Soil Biology and Biochemistry 30:905-916.

Jöreskog, K. G., and D. Sörbom. 1984. LISREL-VI user's guide. Third edition. Scientific Software, Mooresville, Indiana, USA.

Lee, S. Y. 2007. Structural equation modeling: a Bayesian approach. John Wiley and Sons, New York, New York, USA.

Marticorena, B., G. Bergametti, D. Gillette, and J. Belnap. 1997. Factors controlling threshold friction velocity in semiarid and arid areas of the United States. Journal of Geophysical Research 102:23277-23288.

McGonigle, T. P., M. H. Miller, D. G. Evans, G. L. Fairchild, and J. A. Swan. 1990. A new method which gives an objective measure of colonization of roots by vesicular-arbuscular mycorrhizal fungi. New Phytologist 115:495-501.

McKenney, M. C., and D. L. Lindsey. 1987. Improved method for quantifying endomycorrhizal fungi spores from soil. Mycologia 79:779-782.

Mehlich, A. 1984. Mehlich-3 soil test extractant: a modification of Mehlich-2 extractant. Communications in Soil Science and Plant Analysis 15:1409-1416.

Millennium Ecosystem Assessment. 2005. Ecosystems and human well-being: desertification synthesis. World Resources Institute, Washington, D.C., USA.

Miller, R. M. 1979. Some occurrences of vesicular-arbuscular mycorrhiza in natural and disturbed ecosystems of the Red Desert. Canadian Journal of Botany 57:619-623.

Miller, R. M., and J. D. Jastrow. 2000. Mycorrhizal fungi influence soil structure. Pages 3-18 in Y. Kapulnik and D. D. Douds, editors. Arbuscular mycorrhizas: physiology and function. Kluwer Academic Publishers, Dordrecht, The Netherlands.

Moorman, T., and F. B. Reeves. 1979. The role of endomycorrhzae in revegetation practices in the semi-arid west. II. A bioassay to determine the effect of land disturbance on endomycorrhizal populations. American Journal of Botany 66:14-18.

Narjisse, H. 2000. Rangeland issues and trends in developing countries. Pages 181-195 in O. Arnalds and S. Archer, 
editors. Rangeland desertification. Kluwer Academic Publishers, Dordrecht, The Netherlands.

Newsham, K., A. Fitter, and A. Watkinson. 1995. Multifunctionality and biodiversity in arbuscular mycorrhizas. Trends in Ecology and Evolution 10:407-411.

Oades, J. M. 1984. Soil organic matter and structural stability: mechanisms and implications for management. Plant and Soil 76:319-337.

Pellant, M., P. Shaver, D. A. Pyke, and J. E. Herrick. 2000. Interpreting indicators of rangeland health. Version 3. BLM Technical Reference 173:4-6.

Pendleton, R. L., B. K. Pendleton, G. L. Howard, and S. D. Warren. 2003. Growth and nutrient content of herbaceous seedlings associated with biological soil crusts. Arid Land Research and Management 17:271-281.

Pierson, F. B. 2000. Erosion models: use and misuse on rangelands. Pages 67-76 in O. Arnalds and S. Archer, editors. Rangeland desertification. Kluwer Academic Publishers, Dordrecht, The Netherlands.

Renard, K. G., G. R. Foster, G. A. Weesies, and J. P. Porter. 1991. RUSLE: revised universal soil loss equation. Journal of Soil and Water Conservation 46:30-33.

Reynolds, J. F., et al. 2007. Global desertification: building a science for dryland development. Science 316:847-851.

Rillig, M. C. 2004. Arbuscular mycorrhizae, glomalin, and soil aggregation. Canadian Journal of Soil Science 84:355-363.

Rillig, M. C., F. T. Maestre, and L. J. Lamite. 2003. Microsite differences in fungal hyphal length, glomalin, and soil aggregate stability in semiarid Mediterranean steppes. Soil Biology and Biochemistry 35:1257-1260.

Rillig, M. C., S. F. Wright, and V. Eviner. 2002. The role of arbuscular mycorrhizal fungi and glomalin in soil aggregation: comparing effects of five plant species. Plant and Soil 238:325-333.

SAS Institute. 2000. JMP 4.0. SAS Institute, Cary, North Carolina, USA.

Schlesinger, W. H., and A. M. Pilmanis. 1998. Plant-soil interaction in deserts. Biogeochemistry 42:169-187.

Schlesinger, W. H., J. A. Raikes, A. E. Hartley, and A. F. Cross. 1996. On the spatial pattern of soil nutrients in desert ecosystems. Ecology 77:364-374.

Schlesinger, W. H., J. F. Reynolds, G. L. Cunningham, L. F. Huenneke, W. M. Jarrell, R. A. Virginia, and W. G. Whitford. 1990. Biological feedbacks global desertification. Science 247:1043-1048.

Schwab, S., and F. B. Reeves. 1981. The role of endomycorrhizae in revegetation practices in semi-arid western USA. 3. Vertical distribution of vesicular-arbuscular mycorrhizal potential. American Journal of Botany 68:1293-1297.
Shipley, B. 2000. Cause and correlation in biology: a user's guide to path analysis, structural equations and causal inference. Cambridge University Press, Cambridge, UK.

Spaeth, K. E., F. B. Pierson, M. A. Weltz, and W. H. Blackburn. 2003. Evaluation of USLE and RUSLE estimated soil loss on rangeland. Journal of Range Management 56: 234-246.

SPSS. 2006. AMOS 5.0.1. SPSS, Chicago, Illinois, USA.

St. John, T., D. Coleman, and C. Reid. 1983. Association of vesicular arbuscular mycorrhizal hyphae with soil organic particles. Ecology 64:957-959.

Stutz, J. C., R. Copeman, C. A. Martin, and J. B. Morton. 2000. Patterns of species composition and distribution of arbuscular mycorrhizal fungi in arid regions of southwestern North America and Namibia, Africa. Canadian Journal of Botany 78:237-245.

Tennant, D. 1975. A test of a modified line intersect method of estimating root length. Journal of Ecology 63:995-1001.

Tisdall, J. M. 1994. Possible role of soil microorganisms in aggregation in soils. Plant and soil 159:115-121.

Tisdall, J. M., and J. M. Oades. 1982. Organic matter and water-stable aggregates in soils. European Journal of Soil Science 33:141-163.

Toy, T. J., G. R. Foster, and K. G. Renard. 2002. Soil erosion: processes, prediction, measurement, and control. John Wiley and Sons, New York, New York, USA.

UNCCD [United Nations Convention to Combat Desertification]. 1994. Elaboration of an international convention to combat desertification in countries experiencing serious drought and/or desertification, particularly in Africa. U.N. Doc. A/AC.241/27, 33 I.L.M. 1328. United Nations, Geneva, Switzerland.

Vierheilig, H., A. Coughlan, U. Wyss, and Y. Piché. 1998. Ink and vinegar, a simple staining technique for arbuscularmycorrhizal fungi. Applied Environmental Microbiology 64: 5004-5007.

Warren, S. D. 2001. Biological soil crusts and hydrology in North American deserts. Pages 327-337 in J. Belnap and O. L. Lange, editors. Biological soil crusts: structure, function, and management. Springer-Verlag, Berlin, Germany.

Wright, S. F., and A. Upadhyaya. 1996. Extraction of an abundant and unusual protein from soil and comparison with hyphal protein of arbuscular mycorrhizal fungi. Soil Science 161:575-586.

Wright, S. F., and A. Upadhyaya. 1998. A survey of soils for aggregate stability and glomalin, a glycoprotein produced by hyphae of arbuscular mycorrhizal fungi. Plant and Soil 198: 97-107.

\section{APPENDIX}

Climate, soil, and dominant vegetation details of sampled regions within the Grand Staircase Escalante National Monument, Utah, USA (Ecological Archives A019-006-A1). 